\title{
Revenue, Time Horizon, and Land Allocation in China
}

\begin{abstract}
How do local governments allocate land between sectors of the economy in China? The study demonstrates that the revenue structure and the time horizon of local politicians impact the sectoral allocation of local resources. The industrial and tertiary sectors display systematic differences in the way they contribute to local revenue: the former generates a steadier revenue stream in the long run, while the latter generates more sizable and more immediate revenue in the short run. Two institutional constraints, the tenure limit and the age-based retirement for government officials, create variation in the individual time horizon, which in turn influences the way local governments extract revenue. Based on fieldwork and analysis of an original dataset of 120 cities, it finds that local politicians with longer time horizons allocate more land to the industrial sector and accordingly less to the tertiary sector. The results suggest that the distortion in land allocation lies in the institutional design of the revenue structure and the personnel management system in China.
\end{abstract}

Keywords: revenue structure; time horizon of politicians; land allocation; economic distortion; China

\section{Introduction}

The structure of centrally planned economies is distorted compared to market economies, as reflected by a relative overdevelopment of heavy industry and underdevelopment of services (Ofer 1987; Kornai 1992; Roland 2000). The transition from a command to market economy thus requires a shift in resource allocation among sectors of the economy, with an expectation that economic reform will induce the seriously distorted economic structure to move in a direction consistent with market economies. Contrary to this expectation, after more than three decades of economic reforms, the Chinese economic structure still stands in stark contrast to other transitional countries as well as many developing countries. While postcommunist countries experienced a significant structural shift from industry to services, China still maintains a bias toward industry and a relatively small share of services: between 1990 to 2009, value added by industry as a share of GDP declined from 46 to 29 percent in Eastern Europe and the Baltics, from 48 to 33 percent in Russia, and from 39 to 35 percent in other countries in the former Soviet Union (CIS), while in China it increased from 41 to 46 percent. Within the same period, value added by services as a share of GDP grew much

(C) 2016. This manuscript version is made available under the Elsevier user license http://www.elsevier.com/open-access/userlicense/1.0/ 
faster in postcommunist countries than in China: the ratio increased from 39 to 64 percent in Eastern Europe and the Baltics, from 35 to 62 percent in Russia, from 32 to 52 percent in the CIS, and from 32 to only 43 percent in China. Holding time invariant, China's economic structure still stands out in comparison with other developing countries. Those showing a similar pattern of economic structure with China are often oil-rich countries, such as Angola and Azerbaijan. ${ }^{1}$ Both cross-time and cross-sectional comparisons suggest that despite its stunning economic growth, China's economic structure is far from optimal. Huang and Tao (2011) found that economic structure in China suffers from serious distortions in labor, capital, land, energy, and the environment.

This article investigates the political and economic determinants of land allocation between the industrial and service sectors in China. Land is one of the fundamental means of production accommodating economic activities. Furthermore, under the existing institutional setting, land provides local governments with a source of revenue, an instrument with which to intervene in the economy, and a source of collateral to finance local infrastructure (Lin 2009; Hsing 2010; Tao et al. 2010; Whiting 2011; Zhou 2011; Rithmire 2015; Cai 2015, 2016). In 2014 when China's booming real estate market began to slide, revenue generated from transferring state-owned land use rights increased by 3.1 percent only, but was still 4,294 billion RMB, equivalent to 30.6 percent of the state budget (Ministry of Finance 2014).

China's rapid industrialization and urbanization have accompanied a massive loss of arable land. During the period from 1978 to 1996, total arable land shrank from 99.39 to 94.97 million hectares, a net loss of 4.42 million hectares or 4.4 percent. Top leaders in Beijing were shocked by the magnitude of land loss in February 1997 when they were shown Landsat photographs for 1987, 1991, and 1995, in which the rate of conversion from

\footnotetext{
${ }^{1}$ The World Bank, World Development Indicators, available at: http://databank. worldbank.org. The countries in Eastern Europe and the Baltics include Albania, Bulgaria, Croatia, Czech Republic, Estonia, Hungary, Latvia, Lithuania, Macedonia, Poland, Romania, Slovenia, and Slovakia.The countries in the CIS include Azerbaijan, Armenia, Belarus, Georgia, Kazakhstan, Moldova, Tajikistan, Turkmenistan, Ukraine, and Uzbekistan. For a more detailed comparison of economic structure, please see the Online Appendix.
} 
agricultural land to non-agricultural use in seventeen urban regions was two-and-a-half times faster than previously thought (Lin 2009, p. 6). Shortly thereafter, the central government announced a one-year moratorium on arable land conversion into non-agricultural use in May 1997 that was subsequently extended to 1999 (State Bureau of Land Administration and State Planning Commission 1997). In 1998 the central government centralized land management authority and installed a new land quota system with which to restrict land use at the subnational level. ${ }^{2}$ With a more restrictive land management framework, local governments are unable to convert as much arable land as they desire into nonagricultural use. This forces local governments to be more cautious about the sectoral allocation of land resources.

How do local governments allocate land, the total amount of which is restricted and controlled by upper-level authorities, between sectors of the economy? This study demonstrates that the revenue structure and the time horizon of local politicians impact the sectoral allocation of local resources. The industrial and tertiary sectors display systematic differences in the way they contribute to local revenue: the former generates a steadier revenue stream in the long run, while the latter generates more sizable and more immediate revenue in the short run. Two institutional constraints, the tenure limit and the age-based retirement for government officials, create variation in the individual time horizon, which in turn influences the way local governments extract revenue. Using a dataset compiled from various statistical yearbooks and career histories of local politicians from a probability sample of 120 cities at the prefecture level and above, it finds that local politicians with longer time horizons allocate more land to the industrial sector and accordingly less to the tertiary sector. The results suggest that the distortion in land allocation lies in the institutional design of the revenue structure and the personnel management system in China.

\footnotetext{
${ }^{2}$ The quota system was implemented in the 1980s, during which time local governments at various levels in the hierarchical administrative system had power to review requests for land conversion. This system was a failure because of the circumvention and manipulation of local governments. The failure forced the central government to install a new and more restrictive land management framework. For more discussion on the quota system prior to 1998, see Lin and Ho 2005, pp. 422-23.
} 
The study ties in with three strands of literature. A first strand builds on the "grabbing hand" model of government by Andrei Shleifer (1997) and his various coauthors (Murphy, Shleifer and Vishny 1991; Frye and Shleifer 1997; Shleifer and Vishny 1998). A general consensus in this literature is that political factors matter enormously for resource allocation, resulting in inefficient outcomes. For example, Murphy, Shleifer and Vishny (1991) examine the allocation of human capital and find that in countries where rent seekers can claim a substantial part of wealth through official and unofficial expropriation, the most talented people join rent-seeking rather than entrepreneurial activities, thereby reducing economic growth. The experiences of transition economies in postcommunist countries suggest that the state is a central barrier to economic structure (Shleifer 1997; Frye and Shleifer 1997). Along this line, this article examines the role that local governments play in the allocation of land between sectors of the Chinese local economy.

The second strand in the literature begins with the pioneering work of Mancur Olson (1993) examining the incentive structure of politicians. The state is after all staffed by politicians who are themselves subject to institutional restrictions affecting their time horizon. Olson's analogy of roving and stationary bandits best illustrates the logic of time horizon. A "roving bandit" with a short time horizon has a strong incentive to confiscate wealth and abrogate contracts. Such predation destroys the incentive for citizens to engage in productive activity, contributing to a decline in economic output. In contrast, a "stationary bandit" with a long time horizon has an incentive to provide public goods, respect individual property and enforce contracts so as to extract the maximum possible net surplus in the long run. This action encourages citizens to invest and produce, and consequently generates economic growth under a dictatorship. Empirical studies demonstrate that as the time horizon of autocrats varies, they behave differently in protection of property rights and use of foreign aid (Clague et al. 1996; Wright 2008). This study examines the logic of time horizon in the China context and finds support for this line of thought.

The third strand builds on the vast literature on the Chinese political economy. With 
the emergence of land markets, the literature that links land with development in China has been rapidly growing in recent years. The primary focus of this literature has been on the state, its incentive to pursue massive urban sprawl (e.g., Lin 2009; Hsing 2010; Whiting 2011; Rithmire 2015) and the impact of such pursuit on the society - primarily farmers (e.g., Guo 2001; Cai 2003; Van Rooij 2007; Liu, Fang and Li 2014; Cui et al. 2015; Cai 2016; Song, Wang and Lei 2016). To my best knowledge, no research has been done to systematically examine the relationship between local politicians and their behavior in the sectoral allocation of land resources. Tao et al. (2010) found that the industrial and tertiary sectors exhibit different dynamics in local revenue contribution. Building on their findings, this article examines how the sector-based revenue structure interacts with political institutions to influence the way in which local politicians manage local land use and growth.

\section{Local Politicians: Preferences and Institutional Constraints}

This study considers local politicians as the main actors in local resource allocation. A local politician is assumed to be a rational self-interested actor whose preference is to maximize revenue, subject to constraints - a common assumption in the political economy studies (e.g., Bates 1981; North 1981; Levi 1988; Olson 1993). Edmund Burke succinctly asserted over two centuries ago: "The revenue of the state is the state. In effect all depends upon it, whether for support or reformation." 3 The assumption that local politicians are revenue-seeking does not conflict, but is compatible, with the fact that politicians are also office-seeking in the Chinese context. In China where politicians are not constrained by voters, the Communist Party holds the ultimate authority over personnel management (i.e., appointment, promotion, transfer, and removal) of all Party and state main leaders through the nomenklatura system (Manion 1985; Burns 1994; Lam and Chan 1996). Leading officials are evaluated regularly according to a set of performance criteria, by which to induce local officials to act in ways commensurate with the preferences of the Party (Tsui and Wang 2004; Whiting 2000, 2004).

\footnotetext{
${ }^{3}$ Quoted in Pollack 2009, p. 1.
} 
[Table 1 about here]

Table 1 details the performance evaluation of local political leaders ${ }^{4}$ in Foshan, the third largest economy in Guangdong province, following Guangzhou and Shenzhen. Local officials' performance is evaluated along 11 indicators, which could be roughly grouped into three categories: economy, environment, and social security. Each indicator is associated with a baseline score; there are extra points for some, but not all, indicators. Score calculation varies across indicators and is somewhat complicated: a target for each indicator is set prior to the evaluation as a baseline to gauge performance; some indicators are measured dichotomously, indicating whether or not the target has been reached, while others provide a relative measure by ranking performance of all localities subject to evaluation. An examination of the Foshan evaluation system shows that revenue collection is assigned with the highest baseline score, suggesting its priority status among all the indicators. Relatedly, the evaluation is biased toward the promotion of economic growth: five indicators (i.e., indicators 1-4 and 8) are directly related to the local economy; their baseline scores constitute $50 \%$ of the evaluation's total baseline scores. For each of the economic indicators, all localities are ranked, with bonus points rewarded according to rank for those who fulfilled the targets. Those who failed to fulfill the targets will receive fewer points and, in the worst scenario, receive zero points.

Evaluation results have a direct impact on individual reputation and wealth accumulation: local political leaders who received scores above 100 and 90-99 will be rewarded with three-month salaries and two-month salaries, respectively; while those who received 80-89 and below 80 will be penalized by a warning (jingshi) and an internal notification of criticism (tongbao piping), respectively. In addition to the overall evaluation, those who ranked first and second in local revenue collection (i.e., indicator 2) or local fixed-asset investment

\footnotetext{
${ }^{4}$ The local political leaders subject to evaluation include: members of the local Party standing committee, chief and deputy leaders of the local congress, government, political consultive conference, and commission for disciplinary inspection.
} 


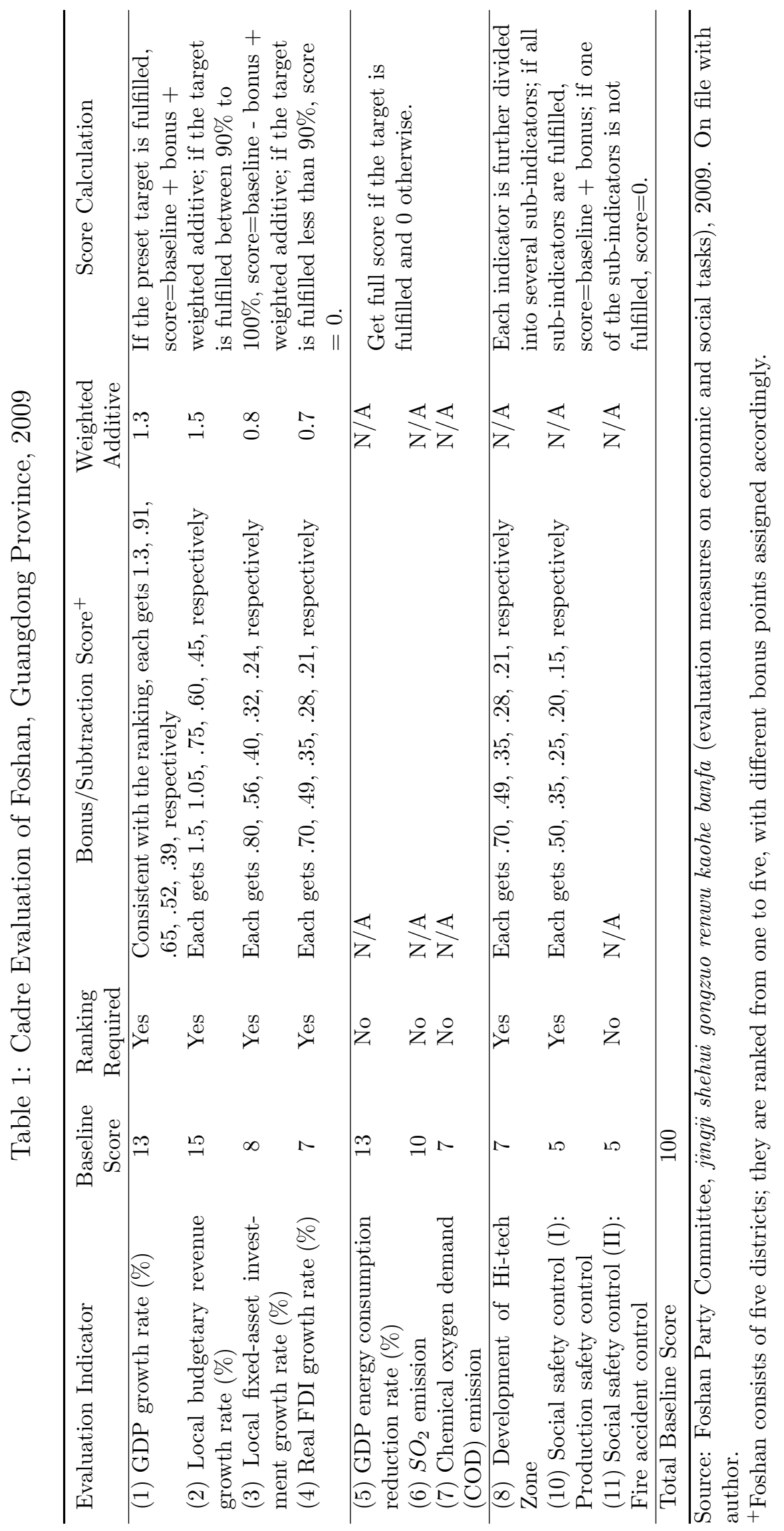


(i.e., indicator 3) will be rewarded with one-month salary, while those who failed to fulfill the targets for either of the two indicators will receive an internal notification. While the amount of material rewards (i.e., a couple months of salaries) may not be attractive to local politicians, who arguably can generate more income elsewhere, it is also related to individual dignity. My interviews with government officials suggest that those who had failed in target fulfillment and thus were penalized felt extremely embarrassed and lost face. More importantly, evaluation results impact individual career advancement. Statistical analysis demonstrates that local officials who achieve higher economic growth are more likely to be promoted (e.g., Li and Zhou 2005; Sheng 2010).

While the evaluation criteria may vary more or less across localities, the form of performance-based evaluation and the emphasis on economic development are nonetheless universal in China (Edin 2003; Landry 2003, 2008; Li and Zhou 2005). Unfortunately, the economic criteria are not easy to fulfill due to budgetary revenue shortfalls. The rapid economic growth in China since the 1990s features a substantial urban bias, massive infrastructural investment, and preferential treatment to large state-owned enterprises and foreign direct investment. This form of growth is conceptualized as "state-led capitalism" that relies heavily on investments from local governments, which are therefore starved for revenue (Huang 2008). However, the existing fiscal framework - the tax sharing system (TSS) launched in 1994 - failed to address the revenue shortfall facing local governments, but made the problem even worse. The TSS successfully transferred revenue from local governments to the center, but failed to adjust expenditure responsibilities for local governments. That is, local politicians experienced a sharp decline in local revenue while they are still expected to take on the same, if not more, expenditure responsibilities, thereby creating the potential for substantial budget deficits (The World Bank 2002; Wong 2009, 2013). The deficit problem appears more severe as one looks down the administrative hierarchy, because a local government has to share its tax collection with all local governments above it administratively, in addition to the central government (Zhou 2006; Oi and Zhao 2007; Wong 2013). The mismatch between 
revenue and expenditure mandates leads local governments to seek intergovernmental fiscal transfers, which, however, fail to offset the fiscal gap (The World Bank 2002; Whiting 2011). Large amounts of intergovernmental transfers are pegged to the size of the local government payroll, meant to guarantee the minimal maintenance of local governments, leaving unsolved the problem of insufficient revenue to promote the local economy (Shih et al. 2010).

Land provides local politicians with a solution to relieve their fiscal stress. While land is segmented into urban land owned by the state and rural land owned by rural collectives, the Constitution also permits the state to expropriate rural land for the sake of the "public interest," a term that is not clearly defined and leaves room for local governments to interpret (Article 10). As a result, it is the state that retains the ultimate authority over all land, urban and rural (Hsing 2010). The introduction of the land leasehold market in 1988 successfully transformed land into a commodity; however, this market is highly distorted and discriminates against rural land. The market of transferring use rights for non-agricultural land is limited to urban land only. That is, rural collectively-owned land must first be converted into urban state-owned land to be legally transferrable in the land market (Land Administration Law, LAL for short hereafter, Article 63). ${ }^{5}$ As a result, the state - the exclusive body with the authority to expropriate land - obtains land from rural households with compensation calculated based on land's agricultural use rather than its future market value (LAL Article 47). Upon completion of land ownership conversion, the state, which monopolizes the primary urban land market, auctions off acquired land to the highest bidder in a fully-funcitioning urban land market. The price differential resulting from the distorted land markets is phenomenal. A 2011 survey of 1,791 rural households across 17 provinces shows that the average compensation that local authorities paid to farmers was approximately 17,850 USD per acre, while they sold land at an average price of 740,000 USD per acre (Landesa 2011).

\footnotetext{
${ }^{5}$ In reality however, there exists an active and pervasive black market where rural land is transferred illegally. See Lin and Ho 2005; Lin 2009; Su, Tao and Wang 2013. The central government has recently allowed local innovations to experiment with a unified market of land for non-agricultural use. See the Chinese Communist Party Central Committee, 2013, Article 11.
} 
Land also provides local governments with an instrument with which to intervene in the local economy. It is not uncommon for local governments to offer their favored investors land at a below-market price in anticipation of the benefits that those investors will generate for the local economy (e.g., jobs, tax revenue). Moreover, local governments create various local financing vehicles (difang rongzi pingtai) whereby state-owned land, a large proportion of which is acquired from rural households and retitled into state ownership, is used as collateral to apply for bank loans with which to build infrastructure. This, in turn, increases the market price of land, generating more revenue when the land is sold. This new revenue allows local governments to acquire more land to continue this cycle. Studies conducted by the Development Research Center of the State Council suggest that land serves as the primary source of collateral for local governments to solicit bank loans with which to operate the economy (Liu and Jiang 2005; Zhou 2011). As such, local governments are desperate to convert agricultural land to non-agricultural use, a process that results in a massive loss of arable land and a widespread of grievances and conflict over land acquisition.

In response, the central government, which has concerns about food security and social stability, substantially revised the Land Administration Law in 1998. This revision recentralized land use decision-making power previously vested at the county- and prefecture-level governments (Lin and Ho 2003). An important tool in this recentralization process is the land quota system, whereby the central government sets farmland preservation goals and creates long-term (10-15 year) and annual land use plans to fulfill the goals. These plans include detailed land quotas - the amount of land allocated for non-agricultural use, the amount of agricultural land to be converted for non-agricultural use, and the amount of arable land to be preserved. These quotas are distributed top-down along the administrative hierarchy: the central government disaggregates national quotas to provinces; each province then disaggregates its quotas to its prefectures, and each prefecture to its counties (The State Council 2014, Article 13). ${ }^{6}$ In addition, the central government has invested in satellite re-

\footnotetext{
${ }^{6}$ Prior to this 2014 regulation, an interim regulation was in effect from 1998 to 2014. Empirically, the allocation of land quotas may vary across localities. In Zhejiang, for example, counties receive land quotas
} 
mote sensing technology to detect local land-use violations and enforce local compliance. My fieldwork evidence reveals that land quotas appeared to be the most binding constraint to some local governments in their promotion of the local economy. To overcome the scarcity of land quota, local governments have developed various mechanisms to trade land quotas between sub-provincial administrative units (Wang, Tao and Tong 2009; Wang et al. 2010; Cai 2015). Some economic development zones create the expected tax contribution per square meter of land as a filter to reject potential investors. A local official in a national-level economic development zone explained the logic behind this filter creation, "We are now short of land [quotas]. ... We no longer accept every firm as we did before. We have changed our development strategies from attracting investment to selecting investment." 7 With the constraint of land quotas, local politicians have to consider how to optimize the allocation of land between sectors of the economy so as to maximize revenue.

\section{Revenue Structure, Time Horizon and Land Allocation}

\subsection{Sectoral Variation in Revenue Contribution}

Revenue structure has a significant impact on state-business relationships and ultimately on economic structure (Easter 2002; Gehlbach 2008). For example, in Russia the vodka sector was created in localities where comparative advantage in the vodka industry is absent. According to Gehlbach (2008), the reason why politicians provided collective goods disproportionally to the vodka industry is because it was easy to tax and thus became an important source of state revenue. Under the 1994 fiscal scheme in China, a local government's tax base is comprised primarily of turnover tax, value-added tax (VAT), and income tax from all enterprises other than central state-owned enterprises. The three forms of taxes combined account for $60-70$ percent of local budgetary revenue. ${ }^{8}$ A close examination of who directly from the provincial government, rather than the prefectural-level government.

${ }^{7}$ Interview with a section chief of the management committee of a national-level economic development zone in Zhejiang, March 19, 2010.

${ }^{8}$ Author's calculation based on a dataset compiled from China Fiscal Yearbook, 1995-2009. 
pays what indicates that the major tax components vary considerably across sectors. Both the industrial and tertiary sectors pay corporate income tax, but the former contributes to VAT, whereas the latter contributes to turnover tax with only a few exceptions, as detailed in Table 2: the construction sector is categorized as industry but pays turnover tax, whereas the wholesale and retail sectors are categorized as services but pay VAT. Manufacturing industry is the largest VAT contributor: about 60 percent of VAT came from manufacturing industry each year from 2001 to $2006 .^{9}$

[Table 2 about here]

Table 2: Sectoral Difference in Tax Contribution

\begin{tabular}{llccc}
\hline & Sectors & VAT & Turnover & Income \\
& & Tax & Tax \\
\hline \multirow{5}{*}{ Industry } & Mining & $\times$ & & $\times$ \\
& Manufacturing & $\times$ & & $\times$ \\
& Production and supply of electricity, gas, and water & $\times$ & & $\times$ \\
& Construction & & $\times$ & $\times$ \\
\hline \multirow{2}{*}{ Service } & Transport, Storage, and Post & $\times$ & $\times$ \\
& Wholesale and retail* & $\times$ & & $\times$ \\
& Finance & & $\times$ & $\times$ \\
& Information transmission, computer, and software & & $\times$ & $\times$ \\
& Business services & & $\times$ & $\times$ \\
& Real estate & & $\times$ & $\times$ \\
& Others & & $\times$ \\
\hline
\end{tabular}

Source: China Tax Yearbooks, 2001-2007.

Note: *The wholesale and retail industry paid both VAT and turnover tax in 2001 and 2002, but paid VAT only from 2003 to 2007.

In addition to tax revenue, the land transfer fees - the dominant component of landgenerated revenue when local governments sell land (use rights) for urban non-agricultural use - also vary considerably across sectors. From a land use perspective, non-agricultural land is categorized into land for industrial, commercial, and residential uses, the latter two types of land going to the tertiary sector. In general, land for commercial and residential use generates much higher land transfer fees than does land for industrial use, as shown in

\footnotetext{
${ }^{9}$ Author's calculation based on China Tax Yearbook, 2002-2007.
} 
Figure 1: the former constantly generated four to nine times more fees than did the latter from 2004 to 2008.

[Figure 1 about here]

Figure 1: Sectoral Difference in the Land Transfer Fees

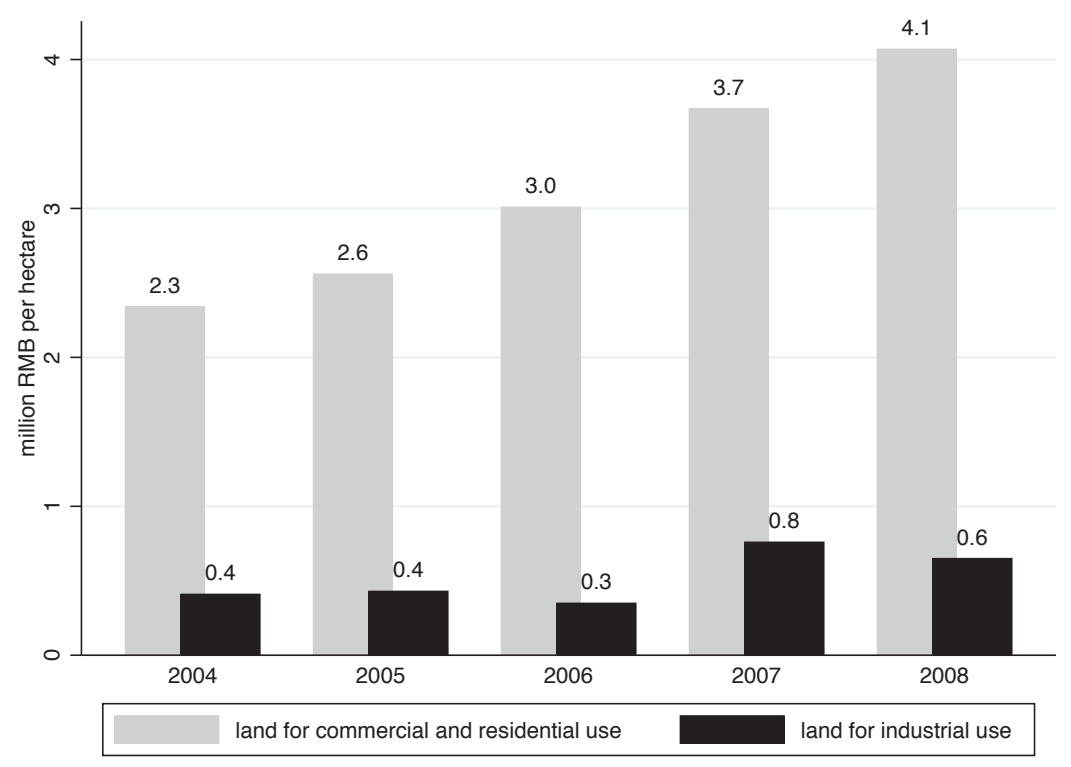

Source: China Land and Resources Statistical Yearbooks, 2005-2009.

Note: Reported data are aggregated at the national level.

The sectoral difference in revenue contribution is partly caused by the use of different land (use rights) sale methods. Local governments have four ways of transferring land use rights: one-on-one negotiation between local governments and potential land users, bid invitation, auction, and listing. In any of the last three approaches, the price of land is driven primarily by market forces and is generally substantially higher than negotiated prices. Nontransparent negotiation between local officials and firms has played a dominant role in transferring land for industrial use, as shown in Figure 2: in the period from 2003 to 2006, about 95 percent of land for industrial use was transferred through negotiation. It was not uncommon for local politicians to offer their favored investors land at a below-market price and, in the most extreme cases, free of charge (Jiang, Liu and Li 2007; Tao et al. 
2010). In response, in August 2006 the central government required local governments to publicly announce a minimum price below which land for industrial use would not be sold. Moreover, negotiated sales were prohibited and replaced by market approaches (the State Council 2006, Article 5). However, my fieldwork evidence reveals that local government officials have developed a variety of strategies to get around this restriction. For example, some local governments add more eligibility filters in a way such that the targeted firm will likely be the only remaining competitive bidder. Another method is to react strategically to the requirement of public notification of a land auction - a procedure designed by the central government to increase transparency of land sales - by placing the notification in small font in an easily neglectable place of local newspapers usually on Fridays in an anticipation that fewer people will read during weekends. Some local officials first agree upon a land price with their desired firm through negotiation, but still let the firm go through the auction procedure by which the firm wins the bid by offering the highest price, and finally return to the firm the difference between the auctioned price and the negotiated price as a bonus of some sort (Cai 2015). In any case, despite central regulations, land sales to the industrial sector at negotiated below-market prices continue. In contrast, market approaches have increasingly dominated the way in which land for commercial and residential use is sold. As shown in Figure 2, the proportion of such land sold through market approaches steadily increased from $55 \%$ in 2003 to $90 \%$ in 2008 .

[Figure 2 about here]

If local politicians are revenue maximizers, as assumed in this article, why do they sell land at a below-market price? More interestingly, why do they do it only for the industrial sector but not the tertiary sector? Tao et al. (2010) argues that manufacturing facilities are generally footloose; this mobility empowers firms and intensifies competition among local governments. To prevent firms from moving elsewhere, local governments have to offer lower land prices. In contrast, the service sector is generally locality-specific; this lack of mobility allows local governments to raise land prices by auctioning off land. In addition, the devel- 
Figure 2: Sectoral Difference in Land Sale Methods

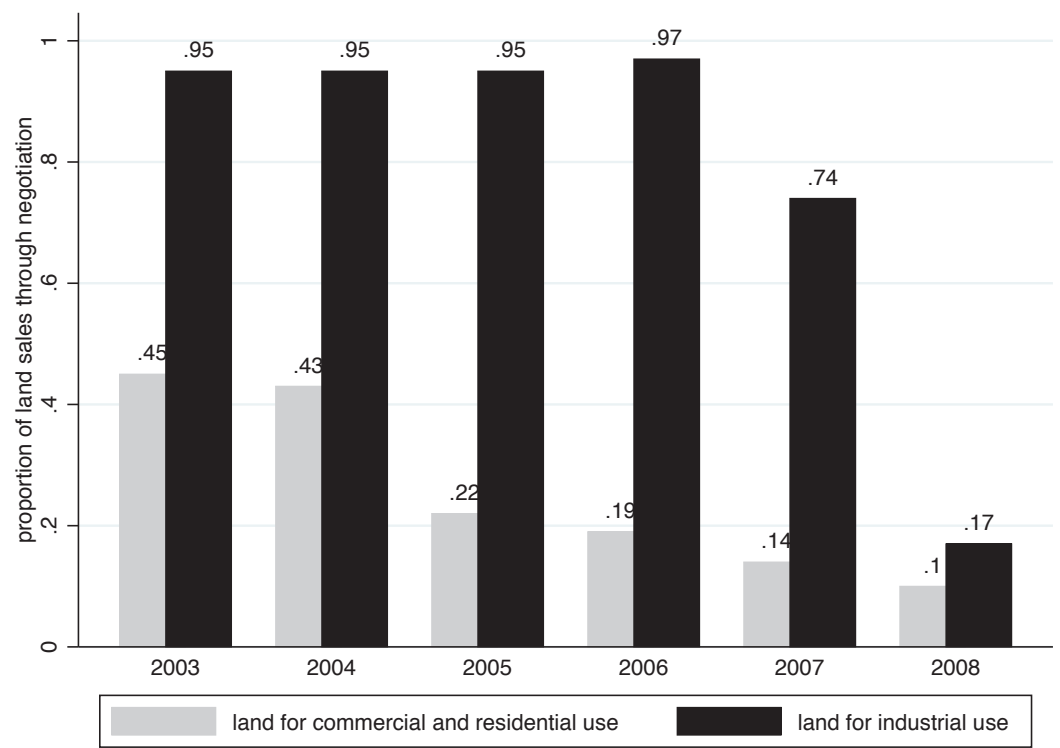

Source: China Land and Resources Statistical Yearbooks, 2004-2009.

Note: Reported data are aggregated at the national level.

opment of the manufacturing industry has a spillover effect on the economy: manufacturing firms create job opportunities, which in turn create demand for housing, entertainment, and shopping, all contributing to the development of the local service sector. For example, aiming to become the largest laptop production base in Asia, the Chongqing Xiyong Microelectronic Industrial Park successfully attracted HP and Foxconn (Apple's manufacturer) through cheaper land prices along with other favorable policies, anticipating that the two well-known firms would attract smaller information technology firms to boost the local economy. $^{10}$

Although the service sector generates more land transfer fees than the industrial sector, such revenue is a one-time payment. Once land is sold, no additional land revenue is available. Local governments can maintain steady revenue only if they keep selling land, which is already a scarce resource in many localities and subject to tightening quota control. In a

\footnotetext{
${ }^{10}$ Interview with a group of officials from the management committee of the Xiyong Industrial Park, Chongqing, May 11, 2010.
} 
similar fashion, the turnover tax generated by the service sector has an initial spurt but stabilizes at a low level afterward (Tao et al. 2010). The real estate sector, the primary contributor to the local turnover tax, produces high turnover tax at the time when houses are sold. Unlike many developed countries, China has not introduced a property tax. Once house sales are over, local turnover tax drops quickly. That is, the local turnover tax can be maintained at a certain level only if there is a booming real estate market where new houses are continually being sold. In contrast, regional competition forces local governments to offer the industrial sector favorable policies (e.g., cheaper land and tax holidays). Unlike land for commercial and residential use, land sales to the industrial sector is generally not a substantial source of revenue for local governments. The industrial sector is also less likely to generate high revenue at the early stage and often has a longer take-off period. However, it can generate sustainable taxable income a few years later because, unlike services, manufacturing firms generate VAT as long as they are producing. Moreover, it has a potential to stimulate the growth of services in the long run. In short, there is a trade-off in the local revenue contribution between the industrial and service sectors once time is taken into account: services generate more sizeable revenue from land sales and turnover taxes in the short run, whereas industry produces a steadier tax revenue stream in the long run.

Applying Mancur Olson's logic on the time horizon of politicians (1993) to resource allocation in China now becomes straightforward. A local politician with a long time horizon, like a stationary bandit, is more likely to allocate more land to the industrial sector, generating sustainable local economic growth and steadier revenue flows in the future. A local politician with a short time horizon, like a roving bandit, will distribute more land to the service sector, generating more immediate and more sizable revenue in the short run.

\subsection{Time Horizon of Politicians and Land Allocation Strategies}

In the China context, two institutional arrangements of the personnel management system influence the time horizon of government officials. The first is the mandatory retirement 
system, which sets a maximum value on the expected remaining political life for officials. In an effort to streamline and rejuvenate the cadre corp, age-based retirement from office was introduced to replace de facto lifelong tenure in 1982 (Manion 1993). ${ }^{11}$ The rules generally set retirement ages at 55 for women and 60 for men. Officials in specified positions of leadership retire later, at 60 or $65 .{ }^{12}$ Empirical studies demonstrate that the implementation of mandatory retirement policy improved over time, and it is now strictly enforced (Li and Zhou 2005; Landry 2008).

The second is the rule of rotation introduced in 1990 that sets a tenure limit for a particular position. To prevent the entrenchment of local political bosses, a leading official of a local Party committee and government must be transferred if he or she has worked in the same position for ten years. Officials can be transferred between different localities, departments, levels of government, and across Party, government, enterprises and public organizations (Chinese Communist Party Central Committee 2002, Article 52). ${ }^{13}$ Positions in Party committees and governments at the county level or above have a term of five years. That is, no one can stay in the same position for more than two terms. By the end of the second term in post, a politician faces one of the following political fates: promotion within the same locality or elsewhere, transfer to a position of identical bureaucratic rank, exit from office if he reaches retirement age, and, in the worst case, removal from office for some reason (e.g., corruption).

While the time horizon of politicians is not easy to measure, the two institutional ar-

\footnotetext{
${ }^{11}$ The central government started promoting the retirement reform for officials in 1978. Between 1978 and 1981, the retirement age was set in regulations, but the criteria of poor health and inability to continue work, not old age per se, were the actual determinants of retirement. In 1982 age-based retirement was established as a general rule, without reference to health or ability to perform official duties. For more discussion on age-based retirement, see (Manion 1993).

${ }^{12}$ The following officials, men and women, retire at 65: government ministers and Central Committee department heads, provincial Party committee first secretaries, and provincial governors. The following officials retire at 60: deputy ministers and Central Committee department deputy heads, provincial Party committee secretaries (other than first secretaries), provincial deputy governors, bureau chiefs and their deputies in State Council and Central Committee bureaus, heads and deputy heads in provincial Party committee and provincial government departments, prefectural Party committee secretaries and deputy secretaries, and prefectural mayors and deputy mayors. See Chinese Communist Party Central Committee,1982, Article 3.

${ }^{13}$ Prior to this regulation, an interim regulation was in effect from 1995 to 2002.
} 
rangements discussed above allow us to derive observable implications of the hypothesized relationship between the time horizon of politicians and the sectoral allocation of land resources. It is reasonable to expect that those who are young and still far from retirement and those who have just started a political post are more likely to carry out ambitious goals and have long time horizons. Aiming for career advancement in the future, they are more likely to allocate more land to the industrial sector that produces a more sustainable mode of growth. As they approach their retirement age or move to the end of their term, their time horizons shorten. Knowing they will leave the position, they are less interested in maximizing revenue in the long run - an action that benefits their successors - and consequently allocate more land to the service sector.

\section{Data and Measurement}

I compiled a dataset of 120 cities to test the observable implications of the hypothesized relationship between the time horizon of politicians and the sectoral allocation of land. The 120 cities are a probability sample constructed by the World Bank in its 2005 survey. ${ }^{14}$ The survey selected cities at the prefectural level and above, as shown in Figure 3. In particular, all centrally-directed municipalities, deputy provincial level cities, and capital cities from all provinces except Tibet were included in the sample. The inclusion of additional cities for a particular province depends on provincial GDP. The 120 cities accounted for $70-80$ percent of China's GDP in 2005, when the survey was conducted. Economic and administrative data were compiled from various official statistical yearbooks. Data on local politicians were compiled from career histories of city leaders, including both Communist Party secretaries and mayors. The collection of individual career histories was primarily through online sources in Chinese (e.g., Baidu).

\footnotetext{
${ }^{14}$ For more details about the survey, please see The World Bank, 2006, "Governance, Investment Climate, and Harmonious Society: Competitive Enhancement for 120 Cities in China," Report No. 37759CN, available at: http://siteresources.worldbank.org/INTCHINA/Resources/318862-1121421293578/ 120cities_en.pdf.
} 
[Figure 3 about here]

The allocation of land between the industrial and service sectors is the dependent variable. Ideally, we want to know how much land is allocated to each sector. With this data unavailable, land allocation between the two sectors is proxied by land sales through nonmarket and market approaches, because land for industrial use was transferred primarily through negotiation prior to 2007, while land for commercial and residential use has been transferred primarily through market approaches, as shown in Figure 2. In 2006, 97 percent of land for industrial use was sold through negotiation and 81 percent of land for commercial and residential use was sold through market approaches. ${ }^{15}$ I use the ratio of land sales through negotiation to the total amount of land sales to measure land allocated to the industrial sector. As a ratio is bounded between 0 and 1, a logit transformation is employed to convert the bounded dependent variable into an unbounded one. The logit transformation of the dependent variable is normally distributed centering at the mean of 0.7 , meaning that an average of 65 percent of land was allocated to the industrial sector in 2006.

The independent variable of theoretical interest is the time horizon of local government officials, influenced by the tenure limit and the age-based retirement system. For each city, I consider the two most important leading positions: Party secretary and mayor. Following the literature (Clague et al. 1996), I use the politician's time in office to measure the time horizon due to the tenure restriction. I construct two variables, Party secretary time in office and Mayor time in office, to measure how many years a local Party secretary or a mayor had been holding his current position in year 2005 when the World Bank survey was conducted. Given that both positions are limited to two 5-year terms, both variables are discrete, ranging from 1 to 10 . As a local politician increases his time in office, his time horizon shortens. Such a measure, however, fails to take the term constraint into account: a politician who just starts his second term may have a longer time horizon than the one who

\footnotetext{
${ }^{15}$ As shown in Figure 2, the proxy is less accurate after 2007 when negotiation as a primary way of transferring land for industrial use was prohibited by the central government. In 2008 for example, only 17 percent of such land was transferred using negotiation.
} 
Figure 3: Sample of 120 Cities

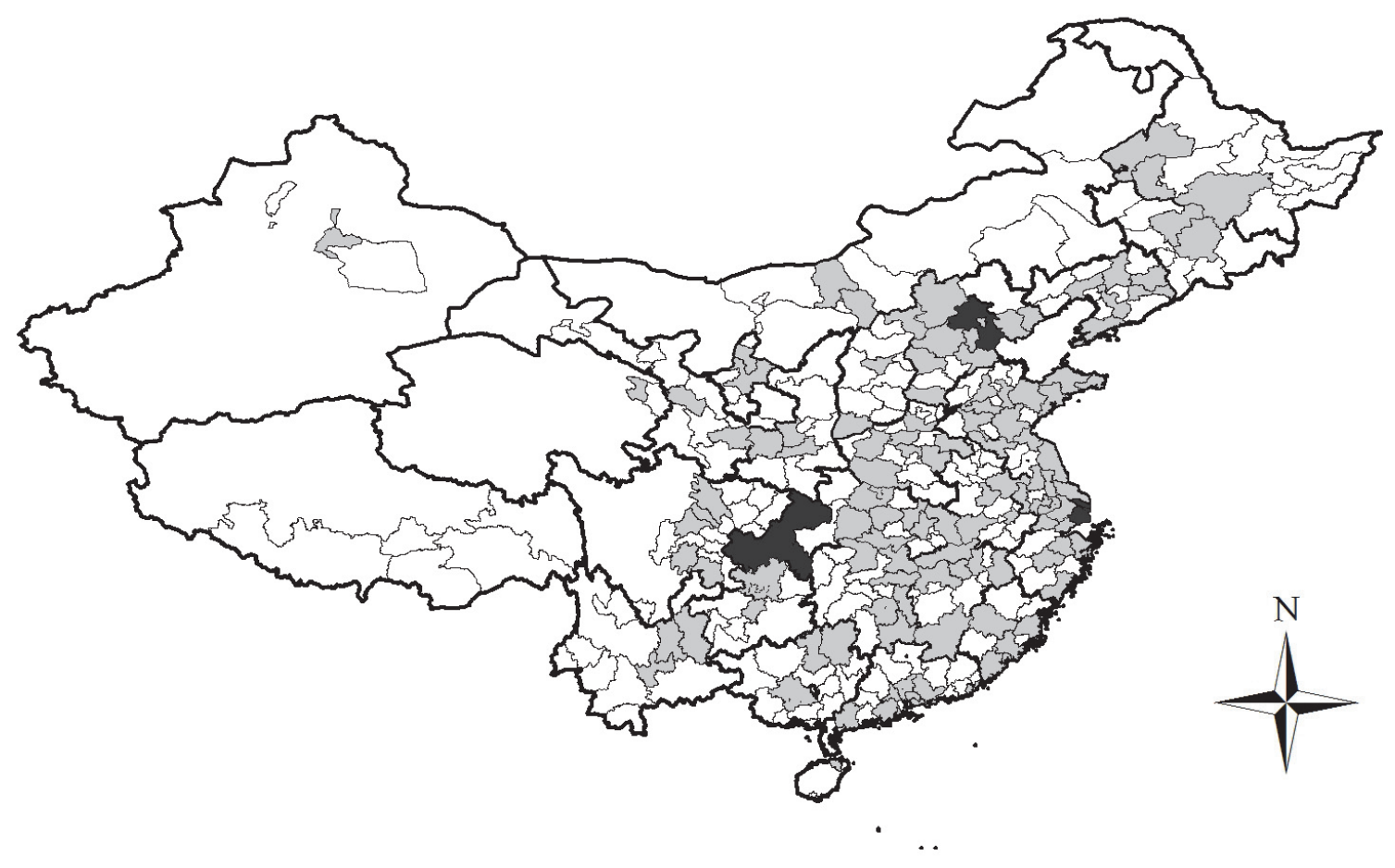

Provincial-level municipalities

Prefectures selected into the sample

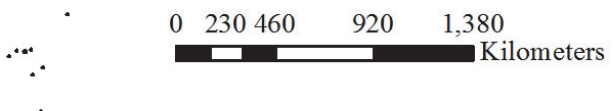


is close to the end of his first term and will not serve the second term. Another concern arises when a politician has not completed his term but already knows that he will be taking a different position elsewhere, causing his time horizon to reach the smallest value even before the end of his full term. That is, the tenure effect on the time horizon may be nonlinear. I add a quadratic form of time in office and a second term indicator for both Party secretary and mayor to address the non-linear relationship concern. In addition to the tenure limit, the time horizon of local politicians is influenced by the age-based retirement system: the time horizon shortens as politicians approach their mandatory retirement age. I use the variable Years to retirement of politicians, constructed by how many years local politicans are expected to work before retirement, to measure the impact of mandatory retirement.

I control for the following factors that may affect local land allocation: Transferred land per person measured by the ratio of the total amount of transferred land to total population, GDP per capita, Economic structure measured by the ratio of the industrial sector to local GDP, Budget deficit measured by the ratio of local budget expenditure to revenue, Urbanization measured by the ratio of urban population to total population, and City dummy to indicate the 19 provincial and deputy-provincial level cities, and Tourist ratio to take into consideration the situation where more tourists in a city may increase the demand for more land to be allocated to the tertiary industry (e.g., hotels, restaurants). Tourist ratio is measured by the proportion of received tourists to the total local population in $2005 .{ }^{16}$

To match the World Bank survey conducted in 2005, all variables are measured for year 2005 with only two exceptions. These two exceptions are the dependent variable and Transferred land per person. While annual land quotas are distributed from above at the beginning of each year, the request for land quotas, which requires the information on sectoral allocation of land quotas, is submitted in the previous year. That is, political leaders who start their appointment in year 2005 are unlikely to be involved in the decision-making on

\footnotetext{
${ }^{16}$ A detailed description of definition and data source of all variables is available in the Online Appendix.
} 
sectoral allocation of land for that year. For this reason, the two land-related variables are measured in year 2006. Table 3 presents summary statistics of the key variables.

[Table 3 about here]

Table 3: Summary statistics

\begin{tabular}{lccccc}
\hline Variable & Mean & Std. Dev. & Min. & Max. & $\mathrm{N}$ \\
\hline Land allocated to the industrial sector & 0.644 & 0.181 & 0.113 & 0.962 & $116^{*}$ \\
Land allocated to the industrial sector (logit) & 0.691 & 0.911 & -2.058 & 3.228 & 116 \\
Party secretary time in office (years) & 3.362 & 1.639 & 1 & 9 & 116 \\
Party secretary time in office squared & 13.966 & 13.341 & 1 & 81 & 116 \\
Party secretary second term indicator (1=yes) & 0.078 & 0.269 & 0 & 1 & 116 \\
Party secretary years to retirement (years) & 7.836 & 3.876 & -1 & 17 & 116 \\
Mayor time in office (years) & 3.345 & 1.61 & 1 & 10 & 116 \\
Mayor time in office squared & 13.759 & 13.774 & 1 & 100 & 116 \\
Mayor second term indicator (1=yes) & 0.078 & 0.269 & 0 & 1 & 116 \\
Mayor years to retirement (years) & 9.379 & 4.333 & 0 & 19 & 116 \\
Transferred land per person (hectare per 10,000 persons) & 2.628 & 2.504 & 0.183 & 15.272 & 116 \\
GDP per capita (log) & 9.753 & 0.622 & 8.34 & 11.146 & 116 \\
Ratio of industries in GDP & 48.599 & 8.968 & 27.18 & 85.92 & 116 \\
Urbanization & 0.405 & 0.2 & 0.116 & 1 & 116 \\
Budget deficit & 1.821 & 0.75 & 0.811 & 5.749 & 116 \\
City dummy & 0.164 & 0.372 & 0 & 1 & 116 \\
Tourist ratio & 1.899 & 1.716 & 0.004 & 10.663 & 116 \\
\hline
\end{tabular}

Note: *Four cities are dropped from the analysis for the following reasons. Two (Baotou and Qiqihaer) are missing for the dependent variable. Two (Quanzhou and Xianyang) have the same person serving concurrently as Party secretary and mayor.

\section{$5 \quad$ Analysis and Discussion}

Table 4 reports the OLS regression results for sectoral allocation of land. Model 1 regresses land allocation on variables that affect the time horizon for the Party secretary only. Model 2 regresses land allocation on variables that affect the time horizon for the mayor only. Model 3 separates the two factors that affect the time horizon of politicians (i.e., tenure limit and agebased retirement) and considers the tenure effect only. Model 4 adds the retirement age effect into the analysis. Models 1-4 suggest that the inclusion of both the tenure and retirement age factors for both Party secretaries and mayors produces better results, as reflected by 
the increase in $R^{2}$. Model 5 drops the four provincial-level municipalities (Beijing, Tianjin, Shanghai, and Chongqing shown in dark gray in Figure 3) from the sample and reruns the Model 4 regression. The results for the key variables of interest remain consistent across all model specifications, suggesting their robustness.

[Table 4 about here]

The regression results suggest interesting findings about how the tenure limit affects politicians in land allocation. First, the coefficients of Party secretary time in office are negative and significant at the 5 percent level (1\% in Model 5), suggesting that as Party secretaries increase their time of holding the position, their time horizon shortens and less land is allocated for the industrial sector, consistent with the hypothesis.

Second, and perhaps more striking, is the opposite signs associated with time in office squared for Party secretary and mayor. The positive and statistically significant coefficient of the squared term for Party secretaries indicates a convex relationship between the time of holding the position and land allocation for Party secretaries. That is, the relationship is parabolic with its vertex oriented downward, meaning that as Party secretaries increase their time in office, the amount of land allocated to the industrial sector first decreases and then increases. In contrast, the coefficient of the squared term for mayors is negative and statistically significant, suggesting a concave relationship. That is, as mayors increase their time in office, the amount of land allocated to the industrial sector first increases and then decreases. In addition, the coefficients of second term indicator for both Party secretaries and mayors are statistically significant across all model specifications but the signs are opposite. Party secretaries in their second term allocate less land to the industrial sector than those in their first term, while mayors in their second term allocate more land to the industrial sector than those in their first term.

Why do Party secretaries differ from mayors in the sectoral allocation of land as their time in office increases? A possible explanation lies in their prospects of career advancement. Given the pyramid-shaped administrative structure in China, the odds of promotion are lower 
Table 4: OLS Estimates for Land Allocated to the Industrial Sector

\begin{tabular}{|c|c|c|c|c|c|}
\hline & (1) & (2) & (3) & (4) & (5) \\
\hline Party secretary time in office & $\begin{array}{c}-0.526^{* *} \\
(0.226)\end{array}$ & & $\begin{array}{c}-0.507^{* *} \\
(0.229)\end{array}$ & $\begin{array}{c}-0.523^{* *} \\
(0.231)\end{array}$ & $\begin{array}{c}-0.870^{* * *} \\
(0.221)\end{array}$ \\
\hline Party secretary time in office squared & $\begin{array}{l}0.061^{*} \\
(0.034)\end{array}$ & & $\begin{array}{l}0.072^{* *} \\
(0.036)\end{array}$ & $\begin{array}{l}0.068^{*} \\
(0.036)\end{array}$ & $\begin{array}{c}0.125^{* * *} \\
(0.034)\end{array}$ \\
\hline Party secretary second term indicator & $\begin{array}{l}-0.695 \\
(0.619)\end{array}$ & & $\begin{array}{l}-1.291^{*} \\
(0.690)\end{array}$ & $\begin{array}{l}-1.136^{*} \\
(0.643)\end{array}$ & $\begin{array}{c}-1.636^{* *} \\
(0.628)\end{array}$ \\
\hline Party secretary years to retirement & $\begin{array}{l}-0.036 \\
(0.022)\end{array}$ & & & $\begin{array}{l}-0.038^{*} \\
(0.021)\end{array}$ & $\begin{array}{l}-0.040^{*} \\
(0.021)\end{array}$ \\
\hline Mayor time in office & & $\begin{array}{c}0.211 \\
(0.173)\end{array}$ & $\begin{array}{c}0.148 \\
(0.150)\end{array}$ & $\begin{array}{c}0.164 \\
(0.142)\end{array}$ & $\begin{array}{c}0.164 \\
(0.139)\end{array}$ \\
\hline Mayor time in office squared & & $\begin{array}{c}-0.048^{* * *} \\
(0.017)\end{array}$ & $\begin{array}{c}-0.046^{* *} \\
(0.018)\end{array}$ & $\begin{array}{c}-0.046^{* * *} \\
(0.016)\end{array}$ & $\begin{array}{c}-0.048^{* * *} \\
(0.016)\end{array}$ \\
\hline Mayor second term indicator & & $\begin{array}{c}1.151^{* * *} \\
(0.374)\end{array}$ & $\begin{array}{c}1.277^{* * *} \\
(0.449)\end{array}$ & $\begin{array}{c}1.311^{* * *} \\
(0.447)\end{array}$ & $\begin{array}{c}1.388^{* * *} \\
(0.454)\end{array}$ \\
\hline Mayor years to retirement & & $\begin{array}{c}0.012 \\
(0.018)\end{array}$ & & $\begin{array}{c}0.012 \\
(0.018)\end{array}$ & $\begin{array}{c}0.011 \\
(0.018)\end{array}$ \\
\hline Transferred land per person & $\begin{array}{c}0.114^{* * *} \\
(0.040)\end{array}$ & $\begin{array}{c}0.174^{* * *} \\
(0.036)\end{array}$ & $\begin{array}{c}0.158^{* * *} \\
(0.040)\end{array}$ & $\begin{array}{c}0.163^{* * *} \\
(0.040)\end{array}$ & $\begin{array}{r}0.169^{* * *} \\
(0.042)\end{array}$ \\
\hline GDP per capita $(\log )$ & $\begin{array}{l}-0.111 \\
(0.414)\end{array}$ & $\begin{array}{l}-0.019 \\
(0.460)\end{array}$ & $\begin{array}{l}-0.215 \\
(0.429)\end{array}$ & $\begin{array}{l}-0.288 \\
(0.428)\end{array}$ & $\begin{array}{l}-0.207 \\
(0.434)\end{array}$ \\
\hline Ratio of industries in GDP & $\begin{array}{l}-0.012 \\
(0.014)\end{array}$ & $\begin{array}{l}-0.017 \\
(0.014)\end{array}$ & $\begin{array}{l}-0.012 \\
(0.014)\end{array}$ & $\begin{array}{l}-0.012 \\
(0.014)\end{array}$ & $\begin{array}{l}-0.008 \\
(0.014)\end{array}$ \\
\hline Urbanization & $\begin{array}{c}1.041 \\
(0.871)\end{array}$ & $\begin{array}{c}1.155 \\
(0.914)\end{array}$ & $\begin{array}{c}1.281 \\
(0.826)\end{array}$ & $\begin{array}{c}1.257 \\
(0.861)\end{array}$ & $\begin{array}{l}1.296 \\
(0.866)\end{array}$ \\
\hline Budget Deficit & $\begin{array}{l}-0.100 \\
(0.200)\end{array}$ & $\begin{array}{c}0.017 \\
(0.234)\end{array}$ & $\begin{array}{l}-0.077 \\
(0.198)\end{array}$ & $\begin{array}{l}-0.155 \\
(0.206)\end{array}$ & $\begin{array}{l}-0.097 \\
(0.193)\end{array}$ \\
\hline City dummy & $\begin{array}{l}-0.236 \\
(0.221)\end{array}$ & $\begin{array}{l}-0.232 \\
(0.231)\end{array}$ & $\begin{array}{l}-0.195 \\
(0.245)\end{array}$ & $\begin{array}{l}-0.241 \\
(0.251)\end{array}$ & $\begin{array}{l}-0.060 \\
(0.268)\end{array}$ \\
\hline Tourist ratio & $\begin{array}{l}-0.040 \\
(0.058)\end{array}$ & $\begin{array}{l}-0.084 \\
(0.064)\end{array}$ & $\begin{array}{l}-0.066 \\
(0.056)\end{array}$ & $\begin{array}{l}-0.067 \\
(0.057)\end{array}$ & $\begin{array}{l}-0.139^{*} \\
(0.078)\end{array}$ \\
\hline Constant & $\begin{array}{c}3.207 \\
(3.656)\end{array}$ & $\begin{array}{c}0.692 \\
(4.303)\end{array}$ & $\begin{array}{c}3.563 \\
(3.856)\end{array}$ & $\begin{array}{c}4.662 \\
(3.849)\end{array}$ & $\begin{array}{c}4.098 \\
(3.884)\end{array}$ \\
\hline$N$ & 116 & 116 & 116 & 116 & 112 \\
\hline$R^{2}$ & 0.274 & 0.251 & 0.321 & 0.344 & 0.382 \\
\hline
\end{tabular}

Source: Author's dataset.

Note: Robust standard errors in parentheses. ${ }^{*} p<0.1,{ }^{* *} p<0.05$, ${ }^{* * *} p<0.01$.

The dependent variable is a logit transformation of the ratio of land sales through negotiation to total amount of land sales, acting as a proxy of the ratio of land allocated to the industrial sector to total amount of land sales. Results without taking the logit transformation are available in the Online Appendix. 
as local politicians move up the career ladder. Thus, mayors who are one level below Party secretaries face a better chance of getting promoted than Party secretaries. Table 5 tabulates the career prospects of Party secretaries and mayors of the 120 cities examined in this study. Among the 120 Party secretaries, 44\% were promoted. The most common career promotion path for Party secretaries at the city level is to become a provincial Party or government leader (e.g., member of provincial Party standing committee or provincial vice-governor). In contrast, $63 \%$ of the 120 mayors were promoted, among which $48 \%$ were promoted to become a city Party secretary locally or elsewhere. This percentage alone already exceeds the total percentage of promotion for Party secretaries (i.e., $48 \%$ vs. 44\%). Mayors who have a more promising career prospect have more incentives to prioritize the development of the industrial sector - an important indicator to evaluate cadre performance, as shown in Table 1 - and increase their chance of career advancement. In contrast, Party secretaries who face a smaller chance of promotion have more incentives to pursue more immediate revenue gain from the tertiary sector and consequently allocate less land to the industrial sector.

$$
\text { [Table } 5 \text { about here] }
$$

Table 5: Career Prospects of Local Politicians in 120 Cities

\begin{tabular}{llcc}
\hline $\begin{array}{l}\text { Career } \\
\text { Future }\end{array}$ & Category & $\begin{array}{c}\text { Party secretary } \\
(\%)\end{array}$ & $\begin{array}{c}\text { Mayor } \\
(\%)\end{array}$ \\
\hline \multirow{3}{*}{ Promotion } & Party secretaries locally or elsewhere at the same level & $\mathrm{N} / \mathrm{A}$ & 48.33 \\
& Provincial Party/government leaders & 36.67 & 9.17 \\
& Party/government leaders of a higher-tier city & 4.17 & 1.67 \\
& National Party/government departments & 3.33 & 3.33 \\
\hline \multirow{3}{*}{ Transfer } & Local Congresses or Political Consultative Conferences & 28.33 & 16.67 \\
& Provincial Party/government departments & 18.33 & 15 \\
& Party/government leaders of a higher-tier city & 4.17 & 2.5 \\
\hline Exit & Retirement & 1.67 & 0.83 \\
& Death & $\mathrm{N} / \mathrm{A}$ & 0.83 \\
\hline Removal & Corruption & 3.33 & 1.67 \\
\hline
\end{tabular}

Source: Author's dataset.

Note: $\mathrm{N}=120$ for Party secretaries; $\mathrm{N}=120$ for mayors.

Using Model 4 to calculate the local extreme value of parabolic distributions, land allocation to the industrial sector reaches its minimum for Party secretaries who have been 
in office for an average of 3.7 years, after which time it begins to increase. In contrast, land allocation to the industrial sector reaches its maximum for mayors who have been in office for an average of 1.8 years, after which time it begins to decrease. The extreme values for both Party secretaries and mayors are reached before the fifth year, the institutionally stipulated end of the full term. ${ }^{17}$ The decision on the sectoral allocation of land resources is made at least one year before land sales take place. This time lag partly explains why the extreme values are reached before the end of the full term. Perhaps more importantly, there exists a systematic difference about the tenure limit in theory and in practice. Despite the formal regulation on tenure length, the Communist Party has nonetheless acted informally to reduce the tenure of chief government executives, resulting in the actual time that some officials serve being shorter than the full term. Using panel data on city mayors from 19902001, Pierre Landry (2008) found that the average length of mayor tenure has been steadily shrinking from 3.2 years in 1990 to mere 2.5 years in 2001. In an examination of county chief executives from 1998 to 2002, Gang Guo (2009) shows that 23 percent of county chief executives in their fourth year were promoted to be Party secretaries locally or elsewhere. As a result, some, but not all, local politicians are expected to update their beliefs - they do not have to wait until they complete the full term to be promoted - and alter their behavior accordingly, resulting in the extreme values reached before the end of the full term. Does the formal term limit still matter if the actual length has been shortened in practice? There is a large variation in the actual time served in office for both Party secretaries and mayors, as reflected by the standard deviation of their time in office in Table 3. That is, while some - perhaps those who have better connections, which are unobservable to researchers, with upper-level authorities - are promoted earlier, many have to serve for the full term. That is, the observation of the shortened average time of serving in office in practice cannot negate the impact of the formal tenure constraint.

\footnotetext{
${ }^{17}$ Strictly speaking, the two values are local extrema. I consider the local extrema are more important because only a few officials at the prefectural level serve the second term. Of the 120 cities examined in this study, only 9 Party secretaries and 9 mayors served the second term.
} 
The coefficient of Party secretary years to retirement is negative and statistically significant, suggesting that as Party secretaries approach their retirement age, they become less interested in long-term revenue and accordingly allocate less land to the industrial sector, consistent with the hypothesis. The coefficient of Transferred land per person remains statistically significant at the 1 percent level across all model specifications, suggesting that more land is allocated to the industrial sector as more land becomes available. As available land increases by 1 square kilometer per 1000 persons, the proportion of land allocated to the industrial sector increases by an average of 3 percent. Four mega cities (Beijing, Tianjin, Shanghai, and Chongqing) are dropped from the sample in Model 5 to take into consideration that the results from Models 1-4 may be driven by the mega cities. The mega cities differ from other cities in our sample in the following ways. First, the retirement age varies with the level of administrative hierarchy: age 65 for political leaders from the provinciallevel municipalities and age 60 for those from deputy-provincial and prefectural-level cities. Second, due to their high administrative status, political leaders from the four mega cities have a smaller chance of further career advancement than those from other types of cities. With mega cities excluded from the sample, the signs of coefficients remain the same and the level of statistical significance for coefficients either remains the same or improves, indicating the consistency of the results across all model specifications.

\section{Conclusion}

This article investigates the relationship between the revenue structure, the time horizon of local politicians, and land allocation strategies in China. It begins with the assumption that local politicians prefer maximizing revenue, lack of which makes it unlikely for them to fulfill unfunded mandates and support rapid urbanization under the post-1994 fiscal system. While scholarly attention on the 1994 reform largely focuses on local budget deficits as a result of revenue-expenditure imbalance (e.g., The World Bank 2002; Wong 2009, 2013), this study highlights another important but somewhat less emphasized consequence: sector-based rev- 
enue structure. Both tax revenues and land transfer fees display systematic variation across sectors; more importantly, time is an important dimension in explaining this variation: the tertiary sector generates significant revenue in the short run while the industrial sector produces a steadier revenue stream in the long run. The time horizon of local politicians interacts with the sector-based revenue structure to influence the way in which local politicians allocate land between sectors of the economy. With a systematic analysis of 120 cities, this study finds that local politicians with longer time horizons allocate more land to the industrial sector and accordingly less to the tertiary sector. Moreover, the time horizon of local politicians is influenced by tenure limits and mandatory retirement ages. In practice, some local politicians are promoted earlier before they complete their full term, resulting in the actual time served in office being shorter than the institutionally stipulated time. Such practice leads a fraction of local politicians to alter their behavior in the sectoral allocation of land resources.

Some scholars argue that the 1994 tax reform encouraged local politicians to shift their economic development focus area from the manufacturing industry to the tertiary sector, because they can keep all turnover tax generated by services at the local level but must surrender 75 percent of VAT generated by the manufacturing industry to the central government (Zhou 2006; Jiang, Liu and Li 2007). Following this logic, we would expect a rapidly growing tertiary sector. This expectation contradicts reality, however. The comparison between China and the rest of the world at the beginning of this article suggests that China has an overdeveloped industrial sector and underdeveloped services. The findings of this study provide some insight into this distorted economic structure. First of all, the distorted land market where farmers are excluded from land conveyance and the state monopolizes the supply of land in the primary land market enables the state to manipulate the price of land. Selling land at below-market prices reduces firm's cost and stimulates the growth of the industrial sector. Indeed, China has witnessed a proliferation of development zones, the process of which involved a massive conversion of agricultural land into industrial use 
in the reform era (Lin 2009; Yew 2012). Furthermore, the high turnover of local politicians intensifies the distortion problem. Each time city mayors take a new position, they have an incentive to prioritize the development of the industrial sector to signal to upper-level authorities their achievements. Accordingly, resources are allocated in a way biased toward the industrial sector. As the turnover rate of local politicians becomes higher and the scale of ealier promotion becomes more widespread, the sectoral allocation of resources is expected to be more distorted.

Theoretically speaking, local politicians could allocate all land available to the industrial sector and none to the tertiary sector, or vice versa. Empirically, however, local politicians always provide both sectors with land, no matter how their time horizon varies. Why would we not observe the situation where one sector receives all and the other recieves none? Allocating local resources is complicated. The time horizon of local politicians, highlighted in this study, is by no means the only factor that affects local resource allocation. My fieldwork evidence suggests that local governments are unable to generate sizeable revenue by selling land to manufacturing firms, and more often than not they lose money because the profit from such land sales is not enough to cover the cost of building infrastructure - an action that local governments undertake prior to land sales to attract investors. While local politicians are willing to sacrifice land-generated profit in order to gain steadier tax revenue in the long run, they must balance their budgets. As a result, even those with the longest time horizon, who would prefer to develop the manufacturing industry, have to allocate some land to the tertiary industry to generate revenue, which can be used to offset the revenue loss from land sales to the industrial sector. Similarly, those with the shortest time horizon, who have a strong preference for windfall profits generated from the real estate sector, are forced to allocate some land to the manufacturing industry so as to fulfill mandates from their upper-level authorities. 


\section{Acknowledgements}

The author is grateful to Melanie Manion, Edward Friedman, Scott Gehlbach, David Weimer and anonymous reviewers for helpful comments on the earlier drafts. She also thanks Saul Wilson for his careful editing. Financial support from the National Science Foundation,

the Chiang Ching-kuo Foundation, the Institute for Humane Studies, the University of Wisconsin-Madison and the University of Connecticut is gratefully acknowledged. 


\section{References}

Bates, Robert H. 1981. Markets and States in Tropical Africa: The Political Basis of Agricultural Policies. Berkeley, California: University of California Press.

Burns, John. 1994. "Strengthening CCP Control of Leadership Selection: The 1990 Nomenklatura." The China Quarterly 138:458-491.

Cai, Meina. 2015. "Flying land": Institutional Innovation in Land Management in Contemporary China. In Local Governance Innovation in China: Experimentation, Diffusion, and Defiance, ed. Jessica C. Teets and William Hurst. New York: Routledge pp. 60-83.

Cai, Meina. 2016. "Land for Welfare in China." Land Use Policy 55:1-12.

Cai, Yongshun. 2003. "Collective Ownership or Cadres' Ownership? The Non-agricultural Use of Farmland in China." The China Quarterly (175):662-680.

China Tax Yearbook Commission. 2002. China Tax Yearbook. Beijing: China Tax Press.

China Tax Yearbook Commission. 2003. China Tax Yearbook. Beijing: China Tax Press.

China Tax Yearbook Commission. 2004. China Tax Yearbook. Beijing: China Tax Press.

China Tax Yearbook Commission. 2005. China Tax Yearbook. Beijing: China Tax Press.

China Tax Yearbook Commission. 2006. China Tax Yearbook. Beijing: China Tax Press.

China Tax Yearbook Commission. 2007. China Tax Yearbook. Beijing: China Tax Press.

Chinese Communist Party Central Committee. 1982. "guanyu jianli laoganbu tuixiu zhidu de jueding." (decision on institutionalization of retirement of aging cadres), February 20.

Chinese Communist Party Central Committee. 2002. "dang zheng lingdao ganbu xuanba renyong gongzuo tiaoli." (regulations on selection and appointment of leading Party and government cadres), July 9.

Chinese Communist Party Central Committee. 2013. "guanyu quanmian shenhua gaige ruogan zhongda wenti de jueding." (Decision on some major issues concerning comprehensively deepening the reform), November 12 .

Clague, Christopher, Philip Keefer, Stephen Knack and Mancur Olson. 1996. "Property and Contract Rights in Autocracies and Democracies." Journal of Economic Growth 1(2):243276.

Cui, Ernan, Ran Tao, Travis J. Warner and Dali L. Yang. 2015. "How do Land Takings Affect Political Trust in Rural China?" Political studies 63(S1):91-109.

Easter, Gerald M. 2002. "Politics of Revenue Extraction in Post-communist States: Poland and Russia Compared." Political Theory 30(4):599 -627. 
Edin, Maria. 2003. "State Capacity and Local Agent Control in China: CCP Cadre Management from a Township Perspective." The China Quarterly (173):35-52.

Frye, Timothy and Andrei Shleifer. 1997. "The Invisible Hand and the Grabbing Hand." American Economic Review 87(2):354-358.

Gehlbach, Scott. 2008. Representation through Taxation: Revenue, Politics, and Development in Postcommunist States. New York: Cambridge University Press.

Guo, Gang. 2009. "China's Local Political Budget Cycles." American Journal of Political Science 53(3):621-632.

Guo, Xiaolin. 2001. "Land Expropriation and Rural Conflicts in China." The China Quarterly (166):422-439.

Hsing, You-tien. 2010. The Great Urban Transformation: Politics of Land and Property in China. Oxford: Oxford University Press.

Huang, Yasheng. 2008. Capitalism with Chinese Characteristics: Entrepreneurship and the State. New York: Cambridge University Press.

Huang, Yiping and Kunyu Tao. 2011. "Causes of and Remedies for the People's Republic of China's External Imbalances: The Role of Factor Market Distortion." Asian Development Bank Institute Working Paper No.279 .

Jiang, Shengsan, Shouying Liu and Qing Li. 2007. "Land System Reform and National Economic Growth." Management World 9:1-9.

Kornai, Janos. 1992. The Socialist System: The Political Economy of Communism. Princeton, New Jersey: Princeton University Press.

Lam, Tao-chiu and Hon S. Chan. 1996. "Reforming China's Cadre Management System." Asian Survey 36(4):772-786.

Landesa. 2011. "Landesa 6th 17-Province China Survey." Available from http://www. landesa.org/china-survey-6/ [Accessed May 5, 2016].

Landry, Pierre F. 2003. "The Political Management of Mayors in Post-Deng China." The Copenhagen Journal of Asian Studies 17:31-58.

Landry, Pierre F. 2008. Decentralized Authoritarianism in China: The Communist Party's Control of Local Elites in the Post-Mao Era. New York: Cambridge University Press.

Levi, Margaret. 1988. Of Rule and Revenue. Berkeley, California: University of California Press.

Li, Hongbin and Li-An Zhou. 2005. "Political Turnover and Economic Performance: The Incentive Role of Personnel Control in China." Journal of Public Economics 89:1743-1762. 
Lin, George C. S. 2009. Developing China: Land, Politics and Social Conditions. New York: Routledge.

Lin, George C. S and Samuel P. S Ho. 2003. "China's Land Resources and Land-Use Change: Insights from the 1996 Land Survey." Land Use Policy 20(2):87-107.

Lin, George C.S. and Samuel P. S. Ho. 2005. "The State, Land System, and Land Development Processes in Contemporary China." Annuals of the Association of American Geographers 92(2):411-436.

Liu, Shouying and Xingsan Jiang. 2005. "Land Financing and Financial risks - a case study from a developed area in eastern China." China Land Science (5):3-9.

Liu, Yansui, Fang Fang and Yuheng Li. 2014. "Key Issues of Land Use in China and Implications for Policy Making." Land Use Policy (40):6-12.

Manion, Melanie. 1985. "The Cadre Management System, Post-Mao: The Appointment, Promotion, Transfer and Removal of Party and State Leaders." The China Quarterly 102:203-233.

Manion, Melanie. 1993. Retirement of Revolutionaries in China: Public Policies, Social Norms, Private Interests. Princeton, New Jersey: Princeton University Press.

Ministry of Finance. 2014. Land-Generated Revenue and Expenditure in 2014.

Ministry of Land and Resources. 2004. China Land and Resources Statistical Yearbook. Beijing: China Geology Press.

Ministry of Land and Resources. 2005. China Land and Resources Statistical Yearbook. Beijing: China Geology Press.

Ministry of Land and Resources. 2006. China Land and Resources Statistical Yearbook. Beijing: China Geology Press.

Ministry of Land and Resources. 2007. China Land and Resources Statistical Yearbook. Beijing: China Geology Press.

Ministry of Land and Resources. 2008. China Land and Resources Statistical Yearbook. Beijing: China Geology Press.

Ministry of Land and Resources. 2009. China Land and Resources Statistical Yearbook. Beijing: China Geology Press.

Murphy, Kevin M., Andrei Shleifer and Robert W. Vishny. 1991. "The Allocation of Talent: Implications for Growth." The Quarterly Nournal of Economics 106(2):503-530.

National People's Congress. 2004a. "Constitution.".

National People's Congress. 2004b. "Land Administration Law." August 28. 
North, Douglass C. 1981. Structure and Change in Economic History. New York: W. W. Norton \& Company.

Ofer, Gur. 1987. "Soviet Economic Growth: 1928-1985." Journal of Economic Literature 25(4):1767-1833.

Oi, Jean C. and Shukai Zhao. 2007. Fiscal Crisis in China's Township: Causes and Consequences. In Grassroots Political Reform in Contemporary China, ed. Elizabeth J. Perry and Merle Goldman. Cambridge, Massachusetts: Harvard University Press pp. 75-96.

Olson, Mancur. 1993. "Dictatorship, Democracy, and Development." The American Political Science Review 87(3):567-576.

Pollack, Sheldon D. 2009. War, Revenue, and State Building. Ithaca, New York: Cornell University Press.

Rithmire, Meg. 2015. Land Bargains and Chinese Capitalism: The Politics and Property Rights under Reform. New York: Cambridge University Press.

Roland, Gerard. 2000. Transition and Economics: Politics, Markets, and Firms. Cambridge, Massachusetts: The MIT Press.

Sheng, Yumin. 2010. Economic Openness and Territorial Politics in China. New York: Cambridge University Press.

Shleifer, Andrei. 1997. "Government in transition." European Economic Review 41:385-410.

Shleifer, Andrei and Robert W. Vishny. 1998. The Grabbing Hand: Government Pathologies and Their Cures. Cambridge, Massachusetts: Harvard University Press.

Song, Yanan, Mark Yaolin Wang and Xiaoting Lei. 2016. "Following the Money: Corruption, Conflict, and the Winners and Losers of Suburban Land Acquisition in China." Geographical Research 54(1):86-102.

State Bureau of Land Administration and State Planning Commission. 1997. "dongjie feinongye jianshe xiangmu zhanyong gengdi guiding." (Regulation on freezing conversion from cultivated land to non-agricultural construction use), May 20.

Su, Fubing, Ran Tao and Hui Wang. 2013. "State Fragmentation and Rights Contestation: Rural Land Development Rights in China." China 8 World Economy 21(4):136-155.

Tao, Ran, Fubing Su, Mingxing Liu and Guangzhong Cao. 2010. "Land Leasing and Local Public Finance in China's Regional Development: Evidence from Prefecture-level Cities." Urban Studies 47(10):2217-2236.

The State Council. 2006. guanyu jiaqiang tudi tiaokong youguan wenti de tongzhi. (Circular on Intensifying Land Control Related Issues), August 31.

The State Council. 2014. "tudi guanlifa shishi tiaoli." (Implementation Regulations for Land Administration Law), July 29. 
The World Bank. 2002. China National Development and Subnational Finance. Washington, DC: The World Bank.

Tsui, Kai-yuen and Youqiang Wang. 2004. "Between Separate Stoves and A Single Menu: Fiscal Decentralization in China." The China Quarterly (177):71-90.

Van Rooij, Benjamin. 2007. "The return of The landlord: Chinese Land Acquisition Conflicts as Illustrated by Peri-Urban Kunming." The Journal of Legal Pluralism and Unofficial Law 39(55):211-244.

Victor Shih and Luke Qi Zhang and Mingqing Liu. 2010. When the Autocrat Gives: Determinants of Fiscal Transfers in China.

Wang, Hui, Ran Tao and Juer Tong. 2009. "Trading Land Development Rights under a Planned Land Use System: the "Zhejiang Model"." China \&6 World Economy 17(1):6682.

Wang, Hui, Ran Tao, Lanlan Wang and Fubing Su. 2010. "Farmland Preservation and Land Development Rights Trading in Zhejiang, China." Habitat International 34(4):454-463.

Whiting, Susan H. 2000. Power and Wealth in Rural China: The Political Economy of Institutional Change. New York: Cambridge University Press.

Whiting, Susan H. 2004. The Cadre Evaluation System at the Grassroots. In Holding China Together: Diversity and National Integration in the Post-Deng Era, ed. Barry J. Naughton and Dali L. Yang. New York: Cambridge University Press pp. 101-119.

Whiting, Susan H. 2011. Fiscal Reform and Land Public Finance: Zouping County in National Context. In China's Local Public Finance in Transition, ed. Joyce Yanyun Man and Yu-Hung Hong. Cambridge, Massachusetts: Lincoln Institute of Land Policy pp. 125144.

Wong, Christine P. 2009. "Rebuilding Government for the 21st Century: Can China Incrementally Reform the Public Sector?" The China Quarterly (200):929-952.

Wong, Christine P. 2013. Paying for Urbanization in China: Challenges of Municipal Finance in the Twenty-First Century. In Financing Metropolitan Governments in Developing Countries, ed. Johannes F. Linn Roy W. Bhal and Deborah L. Wetzel. Cambridge, Massachusetts: Lincoln Institute of Land Policy.

Wright, Joseph. 2008. "To Invest or Insure? How Authoritarian Time Horizons Impact Foreign Aid Effectiveness." Comparative Political Studies 41(7):971 -1000.

Yew, Chiew Ping. 2012. "Pseudo-Urbanization? Competitive Government Behavior and Urban Sprawl in China." Journal of Contemporary China 21(74):281-298.

Zhou, Feizhou. 2006. "Ten Years after the Tax Sharing System." China Social Science 6:100-115. 
Zhou, Feizhou. 2011. Two Models on Land Financing. In Case Studies on Institutional Change in China, ed. Beijing Tianze Economic Research Institute. Beijing: zhongguo caizheng jingji chubanshe. 